\title{
APPRAISING THE VIABILITY OF QUAIL (CHIHUTA) FARMING. PROSPECTS AND CHALLENGES. A CASE OF BINDURA URBAN FARMERS IN ZIMBABWE
}

\author{
Cuthbert Majoni ${ }^{1}$, Deliwe Tembachako ${ }^{1}$, Anyway Katanha ${ }^{1}$ \\ ${ }^{1}$ Zimbabwe Open University Mashonaland, Zimbabwe
}

\begin{abstract}
Quail production refers to the rearing of birds, meticulously chosen with the use of comparatively exhaustive systems, for meat, eggs or other purposes. The study was carried out in Bindura urban area to evaluate the viability of urban quail farming. A total of 40 urban quail farmers selected through snowball sampling, and 10 key randomly selected informants were interviewed. Semi-structured interview guides were used, addressing such topics as history, ownership, management, opportunities, challenges and business records of urban quail farming in Bindura town, Zimbabwe. A descriptive analysis of data was performed. As shown by the results, the rearing of quails is a new agricultural business in the history of Zimbabwe. The main challenges highlighted by urban quail farmers included inadequate housing facilities, insufficient space, theft, predation, inadequate knowledge, fluctuations in market prices, inability to access credit and misconceptions in urban agriculture policies. Despite the challenges cited above, urban quail farmers manage to provide eggs and meat to their families and relatives. Urban quail farming proved to have the potential to boost family income and reduce poverty to some extent. Also, it provides an opportunity for academic research on the alleged medicinal properties of quails. The study concluded that urban quail farming plays an important, yet unexplored, role for the livelihoods of the urban population. The study recommends policy changes that address the following issues: new developments in urban agricultural planning; awareness and education campaigns for various stakeholders; monitoring and coordinating urban agricultural activities; and provision of loans and other credit facilities. The study also proposes the government to support quail farmers through the establishment of processing facilities for quail products.
\end{abstract}

Keywords: urban agriculture, quail, livelihoods, poverty

\section{INTRODUCTION}

In Zimbabwe, quail farming is a new, rapidly growing industry which keeps attracting many people hoping to earn a living out of the highly promising, apparently lucrative business. Quail farming has been practiced for a long time in other countries around in the world, for instance in Australia (since 1970) and in many Asian countries like India and Japan. In Africa, quails live as wild birds, although quail farms operate in some countries, including Kenya and Nigeria.

Globally, compared to other agricultural sectors, the poultry industry is characterized by rapid growth in both consumption and trade. Poultry production is an important agricultural activity in Africa as it provides animal protein, generates income and offers a reliable basis for barter trade (Kalita et al., 2004; McAinsh et al., 2004). The latter is an important aspect for rural household who offer poultry birds in exchange for small items such as kitchenware, clothes, maize etc. Rural poultry has also been reported to be used for traditional ceremonies and festivals in some cultures (Alders et al., 2007), and therefore it contributes significantly to the livelihoods of the most vulnerable rural households. In a bid to protect urban households from the economic hardships

\footnotetext{
$\bowtie$ MSc Anyway Katanha, Zimbabwe Open University Mashonaland Central Regional Campus. 209 Hay Road, Bindura, Zimbabwe, e-mail: akatanhaa@gmail.com
} 
facing the country, Zimbabweans have engaged in various income-generating activities, including illegal gold panning, selling juice and vegetables in vending carts, second-hand clothing businesses and small backyard agricultural enterprises, to name a few.

The launch of the quail farming business in Zimbabwe has been generally welcomed by both small urban and rural entrepreneurs. There has been an influx of both producers and consumers because of local reports which highlight various benefits deriving from quail products. Allegedly, every part of the bird demonstrates valuable medicinal properties and its meat is full of taste. While this is still to be confirmed by the healthcare community, quails are recently believed to offer a number of advantageous health attributes. The producers have ventured into the project without prior training; therefore, urban quail farmers have limited knowledge about the market. Because of the economic hardships being experienced in the country, most Zimbabweans adopt a risk-taking attitude, venturing into anything that is believed to generate incomes.

Although some studies on quail farming have been conducted elsewhere, the conditions of quail production vary from one area to another, depending on socio-economic, cultural and biological factors (Muchadeyi et al., 2005). Therefore, an investigation in the Zimbabwean context is imperative as it will enable broadening the understanding of the significance of quail breeding in the study area and outlining the challenges faced by farmers.

\section{PURPOSE AND OBJECTIVES OF THE STUDY}

The main purposes of this study are to explore the challenges and opportunities behind quail production in urban areas. Based on the main purposes stated above, the specific objectives are to:

- assess the challenges faced by quail farmers;

- determine the existing opportunities for urban quail farming;

- assess the viability of quail production for the farmers.

Based on the above objectives, the following research questions were advanced to guide this study:

- What are the existing challenges of urban quail farming?

- What are the opportunities for urban quail farming?
- How viable is quail farming to urban farmers?

The study is of significance to different communities, including the government, donors, non-governmental institutions and development agencies, which may gain a better understanding of challenges and opportunities behind quail production in urban areas. The study would allow the aforementioned to implement informed interventions and policy measures meant to improve the urban farmers' livelihood strategies in Bindura Urban. Further, this study adds to the existing body of research and promotes further investigation on quail production in Zimbabwe.

\section{LITERATURE REVIEW}

According to El-Katcha et al. (2015) human population in the developing countries is continually increasing, promoting the need to increase the sources of food, especially including animal protein. Winrock (1992) estimated that by 2020 , the human population of SubSaharan Africa would rise to one billion. Consequently, measures should be put in place to ensure sufficient quantities of food (primarily including animal protein) to cater for the growing population. The consumption of animal protein is vital as it contains important amino acids that are not found in plant protein (Bopape and Myers, 2007). The consumption of meat protein was found to be far below the daily requirement of $200 \mathrm{~g}$, as suggested by (Brennan and Leonard, 2005; FAO and WFP, 2016). Many people are struggling to put a decent meal on the table, let alone having adequate amounts of protein in their diet. This situation calls for smallholder projects so as to provide the resource-constrained group of people with access to animal protein in their diet at affordable prices or at production cost. One such business is quail farming.

Quail production is an agricultural activity that has been seen to contribute much to food security and reduction of poverty (FAO, 2011). According to scholars, backyard poultry (quail, chicken etc.) production has become an important link for programs focused on development and poverty reduction (Aning, 2006). In developing countries, economic challenges and food insecurity are faced by many people engaged in urban farming, including horticulture and rearing of poultry. When it comes to poultry, the urban and rural population of Sub-Saharan Africa is engaged in subsistence and commercial production of domesticated quail. In 
Majoni, C., Tembachako, D., Katanha, A. (2018). Appraising the viability of quail (chihuta) farming. Prospects and challenges. A case of Bindura urban farmers in Zimbabwe. J. Agribus. Rural Dev., 1(47), 49-55. http://dx.doi.org/10.17306/J. JARD.2018.00338

Japan, these birds were domesticated in the $11^{\text {th }}$ century (Chang et al., 2009); Japanese quail is found in Japan and, as a migrating bird, in such countries and territories as Korea, Eastern China, Mongolia and Sakhalin (Mizutani, 2003). Commercial quail production has spread to different nations of the world, including Australia, India and some other Asian countries. Nigeria saw the introduction of quail in 1992 (NRVI, 1994); that year marked the start of commercial production (Akpan and Nsa, 2009). In Zimbabwe, quail farming is a recent initiative which has taken a center stage in households, especially in urban areas, as the production process is fast and provides a quick return on investment. Because most urban dwellers cannot afford the expenses of living in a city, they make efforts to reduce their challenges by engaging in urban farming, including the rearing of quails as a backyard activity.

Quail farming is known to offer offer numerous benefits as it creates employment, becomes a source of income, builds a healthy family, and provides a rich source of protein (Bakoji et al., 2013). In other countries, demand for quail and related products has shown an increase as quails are said to provide medicinal, nutritional and economic benefits (Bakoji et al., 2013). On top of that, Adeyemo and Omkoyi (2012) noted that the farming business provides direct employment (for the farmers and those they employ to keep quails) and indirect employment (for suppliers of goods and services like feeds, drugs and marketing). However, there are some challenges in quail production. Adeyemo and Omkoyi, (2012) noted that the lack of comprehensive empirical data results in poor marketing information which, in turn, can affect effective demand. Also, the birds can be vulnerable to Newcastle disease which affects poultry (Mohamed and Hafez, 2011). Therefore, good management practices need to be put in place to avoid the loss of many birds to this disease which is most prevalent in the study area. Also, predators like dogs, cats and snakes are a threat for poultry production both during the day and night. This is why strong quail cages need to be used to prevent loss of animals. As noted by Maass et al. (2012), feed costs are another challenge faced by small-scale producers, pushing many of them out of business. In order to ensure the continuity of its operations, a business enterprise should generate profits. If costs surpass revenue, the business is not viable and the entrepreneur will experience losses. The other challenge is that domesticated quails do not breed.
Hence, artificial incubators or alternatively a broody hen are needed to bring the eggs to the hatching stage (Naibi, Zahraddeen, Kalla and Nathaniel, 2009). Moreover, for urban and rural farmers with modest resources, it is difficult to purchase artificial incubators to increase production and sales volumes.

\section{METHODS AND MATERIALS}

Bindura is the capital of the province of Mashonaland Central, Zimbabwe. The town has an estimated population of 43,675 according to the 2012 national census conducted by the Zimbabwe Central Statistical Office. The urban population of Bindura are engaged in an array of agricultural and non-agricultural activities, spanning from market gardening to crop production, rearing of poultry and mining. The study was carried out in Chipadze and Chiwaridzo, densely populated suburbs of Bindura (see Figure 1). The two suburbs are primarily residential areas showing some signs of overpopulation, developed with dwellings ranging from low-income single-room apartments to seven-roomed housing units. The study site includes a great marsh area with poor drainage. Bindura Urban is located within the agro-ecological region 2 of Zimbabwe. Annual rainfall ranges between $800 \mathrm{~mm}$ and $847 \mathrm{~mm}$, the wettest and driest months being January and August, respectively. The annual average temperature in Bindura is $19.8^{\circ} \mathrm{C}$.

\section{Research design and methods}

A descriptive survey was used for the purposes of this study. Focus was placed on challenges and opportunities of quail farming in urban Bindura. Field observations, questionnaires and interview surveys were employed to solicit data from a sample of 40 households selected through snowball sampling. Also, five key interviewees from institutions were purposively selected. Data collection instruments consisted of a checklist for field observation, a structured questionnaire for quail farmers and an interview guide for informants. Permissions from responsible authorities to conduct the study were sought because of ethical considerations. For the sake of clarity, the questionnaire and interview guide were pretested prior to the main data collection process.

The farm household data of interest included quail production volumes; access to extension services, credit, and other sources of household income; markets; costs of and returns on quail production. The data was 
Majoni, C., Tembachako, D., Katanha, A. (2018). Appraising the viability of quail (chihuta) farming. Prospects and challenges. A case of Bindura urban farmers in Zimbabwe. J. Agribus. Rural Dev., 1(47), 49-55. http://dx.doi.org/10.17306/J. JARD.2018.00338

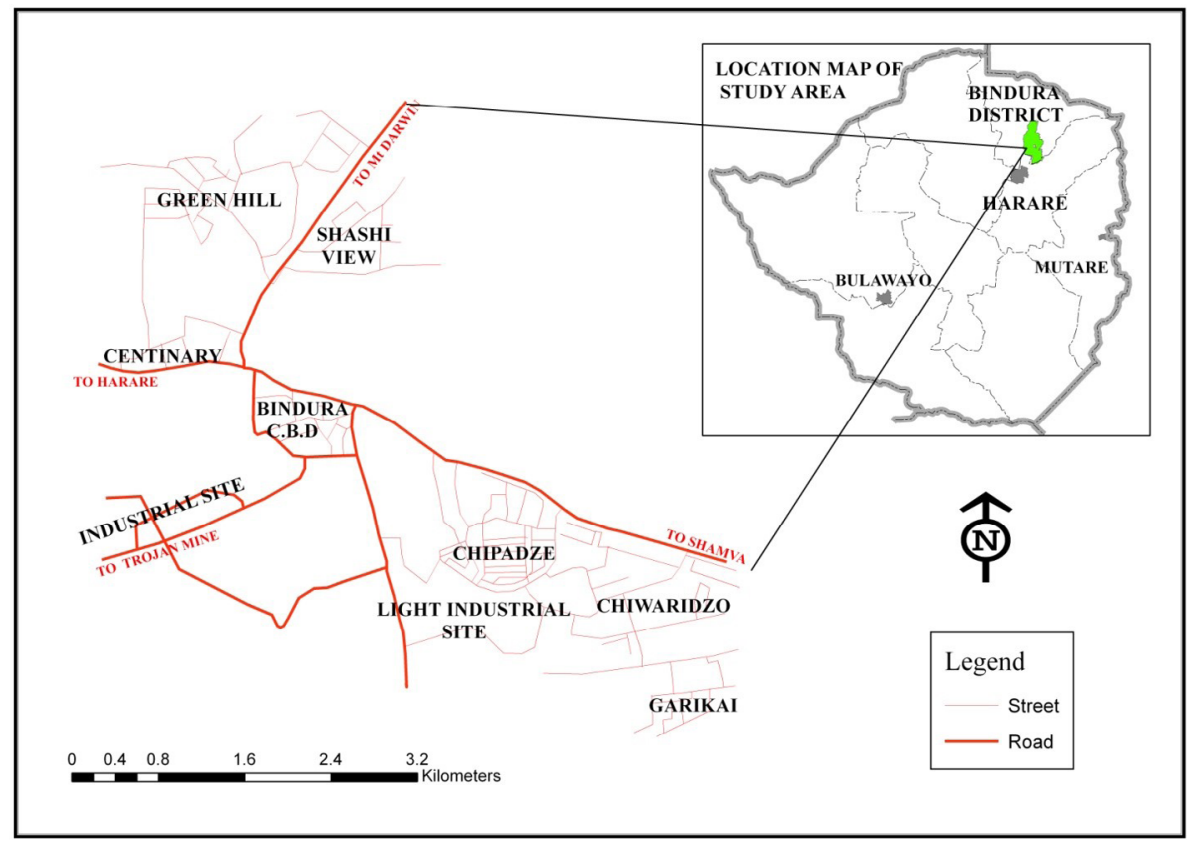

Fig. 1. Study area: map of Bindura Urban, Zimbabwe Source: own elaboration.

analyzed with the Statistical Package for Social Scientists (SPSS). Descriptive statistics were used to evaluate the collected data on quail production, challenges and opportunities. Objective three was analyzed using gross margin analysis to determine the viability of quail production.

\section{Model specification}

The cost of and return on quail production were calculated using the gross margin analysis. Gross margin is the money available to cover the operating expenses and still leave a profit (Downey and Trocke, 1981). Profitability, on the other hand, means the state or condition of yielding a financial profit or gain. Gross margin is specified as follows:

$$
\mathrm{GM}=\mathrm{TR}-\mathrm{TVC} . \mathrm{NI}=(\mathrm{GM}-\mathrm{TFC}) .
$$

Where: $\mathrm{TR}=$ Total Revenue,

$$
\mathrm{TVC}=\text { Total Variable Costs }
$$

$\mathrm{GM}=$ Gross Margin

$\mathrm{NI}=$ Net Income

$\mathrm{TFC}=$ Total Fixed Cost

The gross margin was calculated per 100 birds; egg production was not taken into consideration in this study. Values used in calculating the gross and net margins are the average levels in the 40 farms surveyed.

\section{RESULTS AND DISCUSSION}

People involved in urban quail farming (UQF) are in the $20-48$ age bracket. Approximately $68 \%$ of them are women. The experience of Bindura Urban quail farmers ranges from four months to one and a half years. They keep between 50-1,000 birds per household. Very few ventured into quail farming with prerequisite skills and information on how to rear the birds. Income generated from UQF can be classified into two phases; the criterion for this classification is the moment in time at which the number of breeders increased, and the law of demand and supply could be observed, as explained in the two phases mentioned below.

Phase one was the initial stage of the UQF business in Bindura. At that time, very few people were involved in UQF. The business was promising and received positive publicity from different sectors of the society. The incentives to venture into UQF included high net returns, and the medicinal properties and nutritional value of quail products. Demand for quail and its products 
Majoni, C., Tembachako, D., Katanha, A. (2018). Appraising the viability of quail (chihuta) farming. Prospects and challenges. A case of Bindura urban farmers in Zimbabwe. J. Agribus. Rural Dev., 1(47), 49-55. http://dx.doi.org/10.17306/J. JARD.2018.00338

was high thus commanding high prices. Consequently, a day-old chick was sold at USD 1 while a mature quail fetched between USD 5-6; the price paid for a crate of eggs was USD 4-6. The feeds (believed to be appropriate for quail) were supplied by Capital Foods from Harare, located $89 \mathrm{~km}$ away.

Phase two: more people were attracted to the business of quail bird farming as there were no entry barriers into the enterprise. The economic law of demand came into play: supply increased beyond demand. Naturally, prices go down when supply is high and demand is low. This forced prices to go as low as USD 2 per bird and USD 2-3.50 per crate of eggs. Prices of popular day-old chicks also went down from a dollar to as low as twenty cents. In addition, quail farming (QF) received bad publicity. Adding to the unpopularity of $\mathrm{QF}$, a debate was even held in parliament to determine the authenticity of the medicinal properties of quails. Tables 1 and 2 show the gross margins of quail production in phase one and two, respectively.

Table 1. Quail bird production, phase 1

\begin{tabular}{lccc}
\hline \multicolumn{1}{c}{ Item } & Quantity & Unit price & Total price \\
\hline Chicks & 100 & USD 1 & USD 100 \\
Feeds (1-6 weeks) & $50 \mathrm{~kg}$ & USD 30 & USD 30 \\
Labor (family labor) & - & - & - \\
Total Variable Costs (TVC) & & & USD 130 \\
Total Revenue (TR) 100 $\cdot$ USD 5 & & USD 500 \\
Gross Margin (TR - TVC) & & USD 370 \\
Total Fixed Cost (electricity and water) & & USD 10 \\
Total Cost (TVC + TFC): USD 130 + USD 10 & & USD 130 \\
Net Income (GM - TFC): USD 370 - USD 10 & & USD 360 \\
\hline
\end{tabular}

Source: own elaboration based on the field study.

Table 2. Quail bird production, phase 2

\begin{tabular}{lccc}
\hline \multicolumn{1}{c}{ Item } & Quantity & Unit Price & Total Price \\
\hline Chicks & 100 & USD 1 & USD 100 \\
Feeds (1-6weeks) & $50 \mathrm{~kg}$ & USD 30 & USD 30 \\
Labor (family labor) & - & - & - \\
Total Variable Costs (TVC) & & USD 130 \\
Total Revenue (TR): $100 \cdot$ USD 2 & & USD 200 \\
Gross Margin (TR - TVC) & & USD 70 \\
Total Fixed Cost (electricity and water) & & USD 10 \\
Total Cost (TVC + TFC) & & USD 140 \\
Net Income (GM - TFC) & & USD 60 \\
\hline
\end{tabular}

Source: own elaboration based on the field study. 
Majoni, C., Tembachako, D., Katanha, A. (2018). Appraising the viability of quail (chihuta) farming. Prospects and challenges. A case of Bindura urban farmers in Zimbabwe. J. Agribus. Rural Dev., 1(47), 49-55. http://dx.doi.org/10.17306/J. JARD.2018.00338

\section{CHALLENGES AND OPPORTUNITIES FOR QUAIL FARMING}

The UQF faced a number of challenges that included lack of information on the part of producers and consumers about quail farming requirements and value. In addition, market instability has adversely affected the prices of quail products. Quail bird farmers did not receive any support from the government in the form of agricultural extension services. Predation and theft were also highlighted as some of the challenges faced by the farmers. High transport costs are a hindrance to the acquisition of proper quail feeds. Urban farmers also complained about insufficient space for the expansion of their quail farming projects. Inadequate financial resources to finance and expand their quail businesses by purchasing feeds and incubators have been another stumbling block to small-scale urban quail production.

However, there are some opportunities derived from quail farming. As indicated by the respondents from the study area, substantial income was earned during the first phase of the project. Despite the six-fold decrease in profits in the second phase, the project continues to be viable. Families and the immediate communities are provided with meat and eggs to supplement their dietary needs. Some respondents pointed out that they managed to acquire some household assets, pay fees for their children and even develop their residential stands to some extent.

\section{CONCLUSION AND RECOMMENDATION}

According to findings from this study, quail farming is a viable project capable of sustaining the livelihood of urban farmers. The rearing of quails is an activity that may be undertaken by both urban and rural farmers to improve their living conditions. The study recommends extension workers to contact quail farmers in order to disseminate important information and identify the challenges experienced by farmers. The government is encouraged to support quail farmers in terms of sourcing markets and affordable credit packages. As regards recommendations for quail farmers, they should organize in groups to market their products jointly. Also, there is a need for the media to support quail farmers through awareness and promotional messages targeted at a wide range of customers who lack information, and to reverse the negative publicity about quail products that has been imparted in the minds of consumers.

\section{ACKNOWLEDGEMENT}

We wish to express our gratitude to Bindura Municipality for providing access to information resources and making them available for the purpose of this study. We are grateful to Kamurai Mudzingwa and Dr Eromose Ebhouma for their valued comments and suggestions during the manuscript preparation stage. The authors are grateful to the Reviewers and the Editor for all appreciated comments and suggestions which shaped the scientific value of this study.

\section{REFERENCES}

Adeyemo, A. A., Omkoyi, M. P. (2012). Prospects and challenges of large scale commercial pourltry in Nigeria. Agric. J., 7(6), 388-392.

Akpan, I. A., Nsa, E. E. (2009). Growth performance of growing Japanese quail (Coturnix coturnix japonica) fed diets containing different crude protein levels. In: Proceedings 14th Annual conference of Animal Science Association of Nigeria (ASAN). 14th-17th Sept (pp. 553-555). Ogbomoso, Nigeria: Lautech.

Alders, R., Bagnol, B., Harun, M., Young, M. (2007). Village poultry, food security and HIV/AIDS mitigation. LEISA Mag., 23.

Aning, K. G. (2006). The structure and importance of the commercial and village based poultry in Ghana. FAO.

Bakoji, I., Aliyu, M. K., Haruna, U., Jibril, S. A., Sani, R. M., Danwanka, H. (2013). Economic analysis of quails bird (Cortunix cortunix) production in Bauchi local government area, Bauchi state, Nigeria. Retrieved from https:// www.researchgate.net/profile/Bakoji_Isah/publication/294888382_Bakoji_et_al/data/56c5987208aeeeffa9e 700f8/Bakoji-et-al.pdf

Bopape, L., Myers, R. (2007). Analysis Of Household Demand For Food In South Africa; Model Selection, Expenditure Endogeneity And The Influence Of Socio-Demographic Effects. In: African Econometrics Society Annual Conference. Cape Town, South Africa.

Brennan, L. A., Leonard, A. (2005). Texas quails: ecology and management. Texas A \& M University Press. Retrieved from http://www.tamupress.com/product/TexasQuails,381.aspx

Chang, G. B., Liu, X. P., Chang, H., Chen, G. H., Zhao, W. M., Ji, D. J., Chen, R., Qin, Y. R., Shi, X. K. Hu, G. S. (2009). Behavior differentiation between wild Japanese quail, domestic quail, and their first filial generation. Poult. Sci., 88, 1137-1142. https://doi.org/10.3382/ps.2008-00320 
Majoni, C., Tembachako, D., Katanha, A. (2018). Appraising the viability of quail (chihuta) farming. Prospects and challenges. A case of Bindura urban farmers in Zimbabwe. J. Agribus. Rural Dev., 1(47), 49-55. http://dx.doi.org/10.17306/J. JARD.2018.00338

Downey, W., Trocke, J. K. (1981). Agribusiness Management. New York: Mc Graw-Hill.

El-Katcha, M. I., Soltan, M., Ramdan, S. S., El Naggar, M. K., El-Shobokshy, S. A. (2015). Growth Performance, Blood Biochemical Changes, Carcass Traits and Nutrient Digestibility of Growing Japanese Quail Fed on Various Dietary Protein and Calcium Levels. Alexandria. J. Vet. Sci., 44(1), 38-53.

FAO (2011). Save and grow: a policy-maker'sguide to the sustainable intensification of smallholder crop production. Rome: FAO.

FAO, WFP (2016). Crop and Food Security Assessment Mission (CFSAM): Central African Republic. Special Report. Rome.

Kalita, N., Saikia, P., Baruah, N., Talukdar, J. K. (2004). Economic housing design and stocking densities for rural poultry production in Assam. World. Poul. Sci. J., 60(3), 357-366. https://doi.org/10.1079/WPS200324

Maass, B. L., Katunga Musale, D., Chiuri, W. L., Gassner, A., Peters, M. (2012). Challenges and opportunities for smallholder livestock production in post-conflict South Kivu, eastern DR Congo. Tropic. Anim. Health Prod., 44(6), 1221-1232. https://doi.org/10.1007/s11250-011-0061-5

McAinsh, C. V., Kusina, J., Madsen, J., Nyoni, O. (2004). Traditional chicken production in Zimbabwe. World.
Poul. Sci. J., 60(2), 233-246. https://doi.org/10.1079/ WPS2OO416

Mizutani, M. (2003). The Japanese Quail. Laboratory Animal Research Station, Nippon Institute for Biological Science. Kobuchizawa, Yamanashi, Japan. Retrieved from: http://agrkb.angrin.tlri.gov.tw/modules/icontent/index. php?op= print\&page $=3271$

Mohamed, M. A., Hafez, M. S. A. (2011). The Susceptibility of Japanese Quails to the Infection with Chicken Originated NewCastle Disease Virus. J. Adv. Vet. Res., 6. Retrieved from http://advetresearch.com/index.php/AVR/ article/view/35

Muchadeyi, F. C., Sibanda, S., Kusina, N. T., Kusina, J. F., Makuza, S. M. (2005). Village Chicken Flock Dynamics and the Contribution of Chickens to Household Livelihoods in a Smallholder Farming Area in Zimbabwe. Tropic. Anim. Health Prod., 37(4), 333-344. https://doi. org/10.1007/s11250-005-5082-5

Naibi, S. A., Zahraddeen, D., Kalla, D. J. U., Nathaniel, C. (2009). Effects of storage length and positioning on hatchability of Japanese quail eggs (Coturnix coturnix japonica) in a sub tropical environment. In: Proc. 34th Ann. Conf. Nig. Soc. for Anim. Prod. Uyo (pp. 457 - 460).

Winrock, I. (1992). Assessment of animal agriculture in subSaharan Africa. Morrilton, Arkansas, USA. 